\title{
Effects of Androgens and Antiandrogens on the Conformation of the Androgen Receptor
}

\author{
C. W. KUIL AND E. MULDER \\ Department of Endocrinology and Reproduction \\ Erasmus University Rotterdam \\ P.O. Box 1738 \\ 3000 DR, Rotterdam, The Netherlands
}

Antiandrogens compete with androgens for the androgen receptor (AR) within the target organ. However, the precise molecular mechanism of their antagonism is not well understood. In this paper we describe the use of limited trypsinization and sucrose density gradient centrifugation for the study of androgen receptor conformation and interaction with other proteins.

For this purpose, an in vitro-produced, $\left[{ }^{35} \mathrm{~S}\right]$ methionine-labeled AR was complexed with ligand at $25^{\circ} \mathrm{C}$, whereafter limited trypsinization was performed. Subsequently, the AR fragments were analyzed on a polyacrylamide gel. A 29-kDa fragment of an androgen-bound receptor showed an increased resistance against trypsinization, as compared to an unliganded AR. The antiandrogen cyproterone acetate stabilized a 35-kDa fragment of the AR against proteolytic degradation (FIG. 1). Similar results (not shown) were obtained with several other antiandrogens: hydroxyflutamide, nilutamide, ICI 176.334 and RU 59063. For a mutated receptor (LNCaP-mutant, codon 868: Thr to Ala of an AR of 910 amino acids) ${ }^{1}$ agonistic activity of both cyproterone acetate and hydroxyflutamide correlated with the formation of the $29-\mathrm{kDa}$ fragment. Thus, agonists and antagonists induce different proteolysis-resisting conformations of the AR. ${ }^{2}$ The antiprogestagen RU 486 also has antiandrogenic properties; ${ }^{3}$ after binding of RU 486 to the AR, limited trypsinization formed a $25-\mathrm{kDa}$ fragment and a minor fragment of $29 \mathrm{kDa}$ (FIG. 1). These results indicate a difference in interaction with the AR between the common antiandrogens and RU 486. Immunoprecipitation with a panel of antibodies against the androgen receptor showed that both the 35and $29-\mathrm{kDa}$ fragments contained the entire ligand binding domain, while the $35-\mathrm{kDa}$ fragment extended into the hinge region. ${ }^{2}$ The $25-\mathrm{kDa}$ fragment was truncated at the C-terminus of the ligand binding domain, which conforms to results obtained in comparable studies on protease susceptibility for the progesterone receptor complexed with RU 486. ${ }^{4}$ When incubation was performed at $0^{\circ} \mathrm{C}$ (FIg. 2), or in the presence of molybdate, both androgens and most antiandrogens stabilized a 35-kDa fragment of the AR. In the presence of RU 486 a $35-\mathrm{kDa}$ and $30-\mathrm{kDa}$ fragment of the AR resisted trypsinization. These results indicate a change in proteolysis resisting conformation of the AR upon warming from $0^{\circ} \mathrm{C}$ to $25^{\circ} \mathrm{C}$ for androgens and $\mathrm{RU} 486$, but not for the other antiandrogens. The conformational change of the AR may reflect a process accompanying the dissociation of heat shock proteins (hsp) from the nonactivated hsp-receptor complex. Indeed, sucrose gradient centrifugation showed that an 8S- 


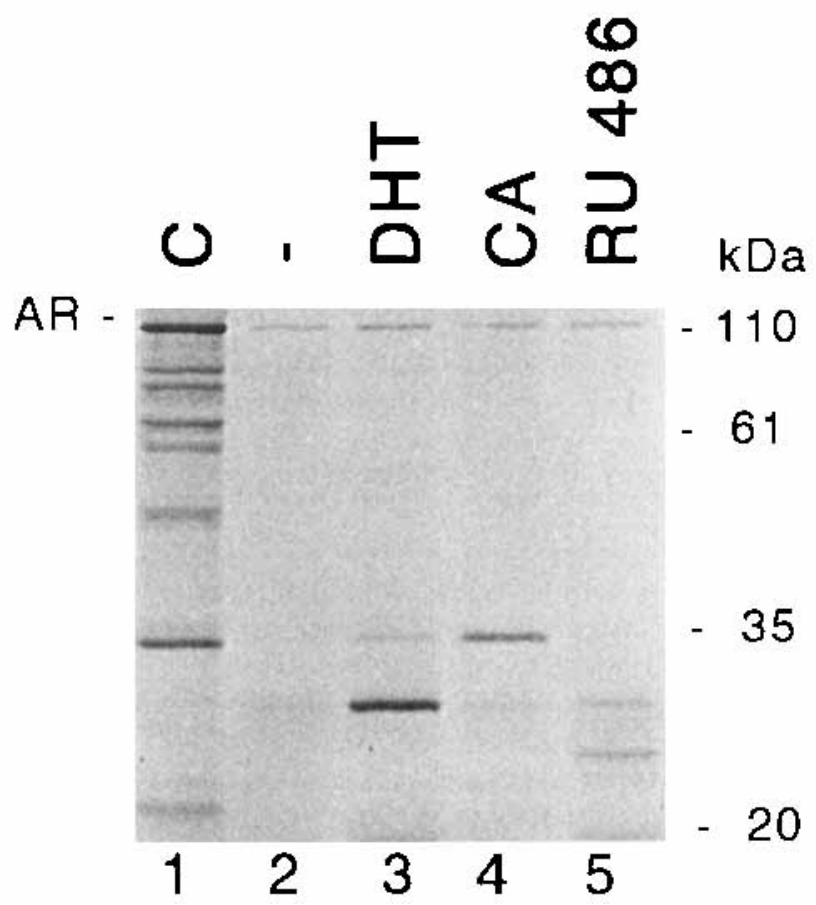

FIGURE 1. Limited trypsinization of androgen- and antiandrogen-bound AR. In vitro-produced, $\left[{ }^{35} \mathrm{~S}\right]$ methionine-labeled AR was incubated $\left(1 \mathrm{~h}\right.$ at $\left.25^{\circ} \mathrm{C}\right)$ in the presence of ligand before limited trypsinization $\left(20 \mu \mathrm{g}\right.$ trypsin $/ \mathrm{ml}, 15 \mathrm{~min}$ at $\left.25^{\circ} \mathrm{C}\right)$. Thereafter the samples were denatured and electrophoresed on a $12.5 \%$ polyacrylamide gel. Autoradiography was performed overnight. ${ }^{2}$ Lane 1 represents control (C) without trypsin, lanes 2-5: vehicle (-), dihydrotestosterone (DHT, $10 \mathrm{nM})$, cyproterone acetate $(\mathrm{CA}, 1 \mu \mathrm{M})$ and RU $486(1 \mu \mathrm{M})$, respectively.

receptor complex shifted, upon warming, to a $5 S$ complex in the presence of androgens and to a $4 \mathrm{~S}$ complex with RU 486. In the presence of other antiandrogens, an 8Sreceptor complex was still present after warming (results not shown).

In conclusion: most antiandrogens increased the stability of the conformation around the hinge region of an in vitro-produced androgen receptor, and did not dissociate the hsp-receptor complex. RU 486, when bound to the androgen receptor, induced an inappropriate conformation at the $\mathrm{C}$-terminus of the ligand binding domain and formed a complex with the receptor with a slower sedimentation rate than observed for complexes with agonists. 


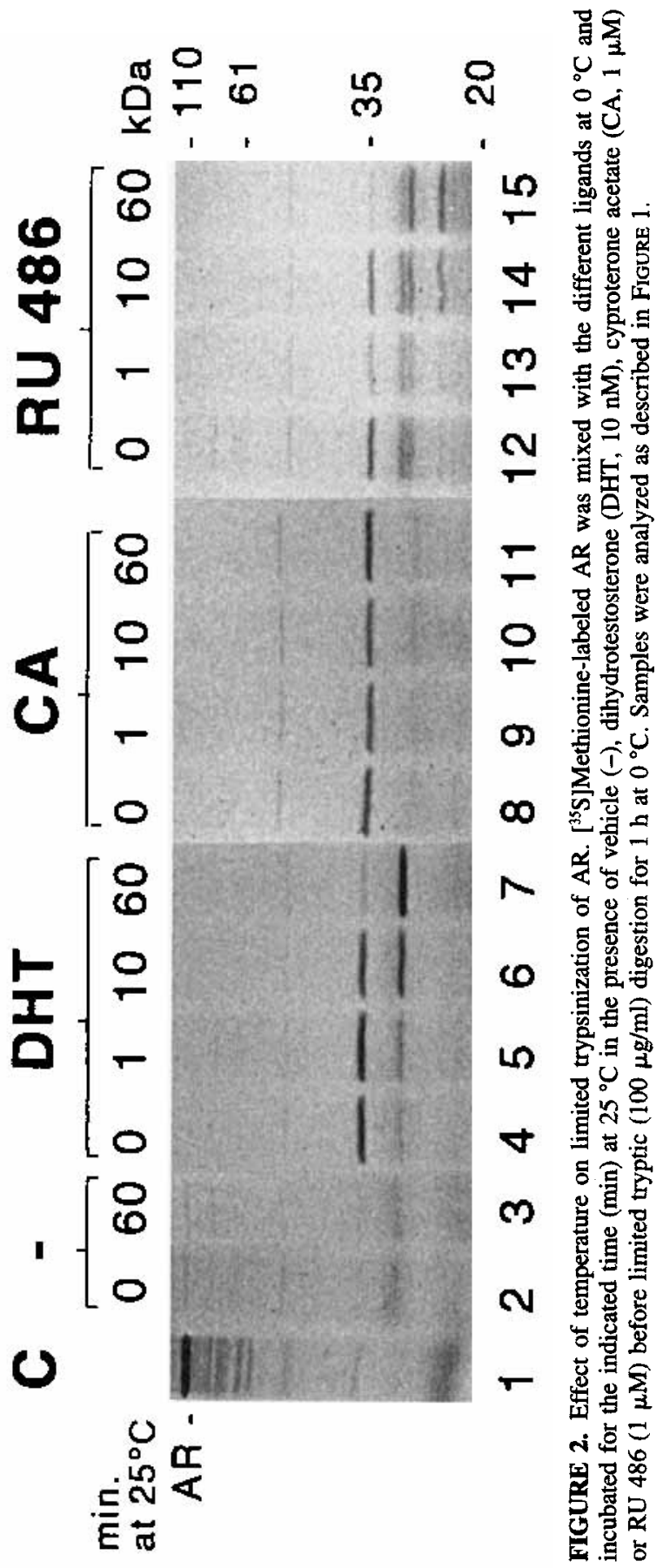




\section{REFERENCES}

1. Veldscholte, J., C. Ris-Stalpers, G. G. J. M. Kutper, G. Jenster, C. Berrevoets, E. Claassen, H. C. J. van Roou, J. Trapman, A. O. Brinkman \& E. Mulder. 1990. Biochem. Biophys. Res. Commun. 173: 534-540.

2. KuIL, C. W. \& E. Mulder. 1994. Mol. Cell Endocrinol. 102: R1-R5.

3. Philibert, D., G. Costerousse, M. Galllard-Mogunlewsky, L. Nedelec, F. Nique, C. Tournemine \& G. Teutsch. 1991. In Frontiers in Hormone Research. M. K. Agarwal, Ed. Vol. 19: 1-17. Karger. Basel, Switzerland.

4. Allan, G. F., X. Leng, S. Y. Tsai, N. L. Weigel, D. P. Edwards, M. J. Tsai \& B. W. O'Malley. 1992. J. Biol. Chem. 267: 19513-19520. 